\title{
Enhancement of Growth and Steroidal Saponins Content in Fenugreek by Foliar Application of Some Growth Promoting Substances
}

\author{
Abdul-Hafeez, E.Y. \\ Ornamental Plants and Landscape Gardening Dept., Faculty of Agriculture, Assiut Uni- \\ versity \\ E-mail: eyhafeez@aun.edu.eg,
}

Received on: 12/3/2019

Accepted for publication on: 17/3/2019

\begin{abstract}
:
Potential therapeutic uses of fenugreek, Trigonella foenum-graecum, are famous in traditional medicine. More recently, it has been revealed that total saponin content in the defatted seed extract is related to the hypocholesterolemic activity of the seeds. Enhancement of growth of fenugreek plant and saponins content in the seeds was the main target of the current investigation. This was attained by the application of all possible combinations of humic acid (1000 ppm), micronutrients foliar fertilizer $(1000 \mathrm{ppm})$ and salicylic acid $(300 \mathrm{ppm})$. Data were recorded on leaf content of chlorophylls ( $a$ and $b$ ) and carotenoids, pods number and weight per plant, seed weight per plant, seed yield per feddan, weight of thousand seed, seed fixed oil percentage, fixed oil yield per feddan and total steroidal saponins in defatted seed extract. Different treatments exerted significant effect for improvement of the measured characteristics. Humic acid alone or combined with either or both of salicylic acid and the foliar fertilizer exhibited the best yield characteristics including seed and oil yields per feddan and total content of steroidal saponins.
\end{abstract}

Keywords: Humic acid, nutrifil, micronutrients, salicylic acid, Trigonella foenumgraecum $L$.

\section{Introduction:}

Fenugreek (Trigonella foenumgraecum L.) belongs to family Leguminosae. It is an annual crop which is native to the Mediterranean region (Petropoulos, 2002), grown as a spice in different regions of the world. It is a cultivated crop in many countries of northern Africa, Europe, Asia, north and south America and Australia (Hardman, 1968, Edison, 1995 and Fazli and Petropoulos, 2002). Fenugreek is one of the oldest known historical medicinal plant (Lust, 1986). Its seeds and leaves have medicinal values for reducing blood sugar and lowering blood cholesterol in humans and animals (Dahanukar et al., 2000). The young plants are used as pot herbs and seeds are considered as a spice or herbal medicine. The seed is an important source of steroidal saponins especially diosgenin which are used extensively by pharmaceutical industries. Diosgenin is often used as a precursor for steroidal drugs and many hormones such as glucocorticoids, testosterone and progesterone (Fazli and Hardman, 1968 and Raghuram et al., 1994). Steroidal saponins was reported by McAnuff $e t$ al. (2002) as effective agents for the treatment of the disorders associated with diabetes.

Micronutrients have been used in improving growth and productivity in fenugreek (Chhibba et al., 2007; 
Pariari et al., 2009 and Aishwath et al., 2011). It has been found by Lal et al. (2015) that spraying fenugreek plants with the three concentrations of zinc $(0.4,0.5$ and $0.6 \%)$, had a considerable effect since the highest number of branches/plant (6.57), number of pods/plant (51.80) and maximum seed yield $(1544.43 \mathrm{~kg} /$ ha.) were obtained with foliar application of $0.5 \%$ zinc. The economic part of fenugreek is seed. So considering the seed production an increased yield of $2.43 \%$ over control was found with applying boron at $0.1 \%$. The highest seed yield was obtained with boron at $0.1 \%$ followed by zinc at $0.2 \%$ and $0.3 \%$ (Pariari et al., 2009).

Humic acid has an essential role in crop farming and soil fertility. The humic substances improve soil fertility and increase the availability of nutrient elements by holding them on mineral surfaces (Tuncturk et al., 2016). It increases cation exchange capacity and enhances soil fertility, converting the mineral elements in to forms available to plants (Stevenson, 1994). Humic substances enhance the uptake of nutrients by the plant root through the transporter proteins localized in the cell membrane (Yilmaz, 2007, Tipping, 2002 and Kulikova et $a l ., 2005)$. It acts as a sponge-like tampon in the wide $\mathrm{pH}$ scale. Its activity may be changed by various $\mathrm{pH}$ levels but neutralizes soil $\mathrm{pH}$, therefore many trace elements can be readily available to the plant. Humic acid exerts beneficial effects on plant growth and development even though some convers exist (Chen and Aviad, 1990 and Padem and Ocal, 1999).
Salicylic acid (SA) as a growth regulator is usually used to regulate growth and flowering of medicinal plants. It is a phenolic compound produced naturally by plants and plays an important role in responses to many of pathogen attack and abiotic stresses (Noreen et al. 2009 and Abdelaal, 2015). The SA has also been investigated for its effects on more physiological processes related to growth and development of plants under control. These effects include flowering induction in herbaceous species (Hegazi and El-Shrayi, 2007), enhancement of root development, as well as stomatal closure and reduced transpiration (Singh and Usha, 2003), conversion of abscisic acid effects (Davies, 2004) and gravitropism regulation (Hussein et al., 2007). As a regulator of flowering, SA has been reported in many plant species of various families (Hayat et al., 2007). In addition to regulate flowering time, SA also links defense responses and reproductive development (Martínez et al., 2004).

The objective of this study was to explore the effects of micronutrients, humic acid and salicylic acid and their combinations on seed yield, production quality and seed steroidal saponin contents of fenugreek.

\section{Material and Methods:}

A field experiment was conducted during the two successive seasons of 2016/2017 and 2017/2018 at the Floriculture Experimental Farm, Faculty of Agriculture, Assiut University, Assiut, Egypt. The experimental design included seven spraying treatments in addition to untreated control: I. Nutrifol (Nu) 1000 ppm. 
(micronutrient fertilizer); II. Humic acid (HA)1000 ppm; III. Salicylic acid (SA) 300 ppm.; IV. Nu 1000 ppm. + HA 1000 ppm.; V. Nu 1000 ppm. + SA 300 ppm.; VI. HA 1000 ppm. + SA 300 ppm.; VII. Nu 1000 ppm. + HA 1000 ppm. + SA 300 $\mathrm{ppm}$. were arranged in randomized complete blocks with three replicates.

Seeds of fenugreek (Trigonella foenum-graecum L. cv. Giza-2) were brought from the Oil Crops Research Department, Agricultural Research Center. Nutrifol contains EDTA che- late micro-nutrients of $\mathrm{Fe}, \mathrm{Zn}, \mathrm{Mn}, \mathrm{B}$, $\mathrm{Cu}, \mathrm{Mo}, \mathrm{Mg}$ and $\mathrm{S}$ produced by Chema industries, Egypt. Humic acid (60 \%) produced by Hebel Monband Water Soluble Fertilizer Co., China. Salicylic acid produced by El-Nasr Co. for Intermediate Chemicals (NCIC), Egypt. The soil physical and chemical characteristics of the experimental field are presented in Table 1 which were done according to the methods described by Jackson (1973) and Black et al. (1982).

Table 1. Characteristics of the clay soil $(30 \mathrm{~cm}$ depths) used at the beginning of the experiment (average of both seasons)

\begin{tabular}{|c|c|c|c|c|c|c|c|c|c|c|c|c|c|c|c|c|c|c|}
\hline \multicolumn{4}{|c|}{$\begin{array}{c}\text { Particle size distribution } \\
(\%)\end{array}$} & \multirow{3}{*}{ 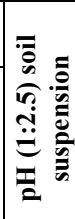 } & \multirow{3}{*}{ 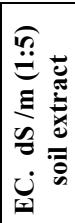 } & \multirow{3}{*}{ 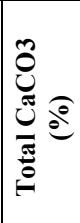 } & \multirow{3}{*}{ 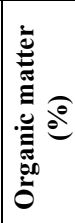 } & \multicolumn{8}{|c|}{ Soluble ions (meq/l, soil paste) } & \multirow{3}{*}{ 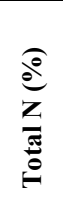 } & \multirow{3}{*}{ 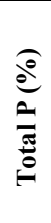 } & \multirow{3}{*}{$\frac{\partial}{0}$} \\
\hline \multirow[b]{2}{*}{ 离 } & \multirow[b]{2}{*}{ 击 } & \multirow[b]{2}{*}{ 吾 } & \multirow[b]{2}{*}{ 递 } & & & & & & & & & & & & & & & \\
\hline & & & & & & & & $\dot{U}$ & 'ొ & 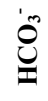 & ") & ${ }_{\pi}^{\ddagger}$ & ${ }^{{ }^{+}} \sum^{\infty}$ & ${ }^{+\pi}$ & \pm & & & \\
\hline 14.33 & 32.86 & 52.47 & Clay & 7.83 & 1.15 & 2.03 & 1.97 & 3.32 & - & 4.94 & 3.05 & 5.40 & 0.52 & 1.30 & 3.89 & 0.55 & 0.21 & 0.41 \\
\hline
\end{tabular}

Plot area was $2 \times 1.5 \mathrm{~m}$ comprising 3 rows $60 \mathrm{~cm}$ apart. Seeds of fenugreek were sown by hand at 25 $\mathrm{cm}$ in row, three seeds in each hole, and thinned after germination (2 seedlings/hole). Seeds of fenugreek were planted in mid-October in the first and second seasons. Foliar sprays of different growth promoting substances were applied four times starting one month after planting and repeated three times at three-week intervals. Samples were selected randomly from plants of the middle row of each plot and data were recorded as follows: leaf content of chlorophylls $(a, b)$ and carotenoids were estimated using the acetone incubation method described by Krishnan et al. (1996). The measurements of yield components were pod number/ plant, pod weight (g/ plant), seed weight (g/ plant), seed yield (kg/feddan), weight of 1000 seed $(\mathrm{g})$, fixed oil percentage and fixed oil yield (1/feddan) in addition to determination of total steroidal saponin in the defatted seeds. All agricultural practices including preparation of soil, sowing of seeds, irrigation, thinning, weed control and harvesting were performed as recommended during the two seasons.

Determination of seed content of steroidal saponins:

After oil extraction by Soxhlet apparatus, $0.1 \mathrm{~g}$ of the defatted residue was collected in a falcon centrifuge tube where $3 \mathrm{ml}$ methanol was added and left overnight on the shaker, followed by centrifugation. The same extraction procedure was done twice more. At the end, super- 
natants of methanol extracts of the three extraction times were pooled together and the solvent was evaporated by the rotary evaporator. A yellowish crystal powder was finally which contained the crude saponins which was spectrophotometrically determined according to the method described by Baccou et al. (1977), Uematsu et al. (2000) and Wang and McAllister (2010) with slight modifications. $2 \mathrm{ml}$ of ethyl acetate was used to dissolve the dry samples containing steroidal saponins, to which 1 $\mathrm{ml}$ of $0.5 \%(\mathrm{v} / \mathrm{v}) p$-anisaldehyde in ethyl acetate and $1 \mathrm{ml}$ of $50 \%(\mathrm{v} / \mathrm{v})$ $\mathrm{H}_{2} \mathrm{SO}_{4}$ in ethyl acetate was added. The mixtures were then left at $60^{\circ}$ for $10 \mathrm{~m}$ for reaction and color development. Saponin present in samples is deglycosylated via acid hydrolysis, such that chromophore development arises from total saponin+sapogenin in a sample. After incubation, tubes were cooled with a cold tap water bath and an aliquot of $0.5 \mathrm{ml}$ of distilled water was added to each sample. The chromophore developed in the deglycosylated samples via acid hydrolysis was measured at $430 \mathrm{~nm}$ absorbance in a spectrophotometer (UV OPTIZEN POP, Korea). The control blank for the measurement was ethyl acetate assayed in similar manner. For the calibration curve, 4-40 $\mu \mathrm{g}$ standard diosgenin in $2 \mathrm{ml}$ ethyl acetate was used.

Data was statistically analyzed using "F" Test (Snedecor and Cochran, 1989) and L.S.D. value for comparison between means of treatments according to Steel and Torrie (1982). Statistical analysis was performed using Statistix 8.1 program.

\section{Results and Discussion:}

Data presented in Table 2 showed that application of different growth promoting substances; Nutrifol, Humic acid, Salicylic acid and their combination among both or all of those substances exhibited considerable significant variations in all parameters studied during both seasons except the carotenoids content in the second season. Nutrifol (micronutrients) individually competes with humic acid to overcome the salicylic acid and the control plants. Nutrifol recorded the best values in chlorophyll "b", carotenoids, number of pods and the fixed oil percentage parameters. Humic acid individually recorded the highest values in the other parameters in competition with Nutrifol and untreated plants. 
Table 2. Effect of foliar application of growth promoting substances on leaf pigments content and pod characteristics of fenugreek plants during 2016/2017 and $2017 / 2018$ seasons.

\begin{tabular}{|l|c|c|c|c|c|c|c|c|c|c|}
\hline \multirow{3}{*}{ Treatments } & \multicolumn{2}{c|}{$\begin{array}{c}\text { Chlorophyll } \\
\text { "a" }\end{array}$} & \multicolumn{2}{c|}{$\begin{array}{c}\text { Chlorophyll } \\
\text { "b" }\end{array}$} & \multicolumn{2}{c|}{ Carotenoids } & \multicolumn{2}{c|}{$\begin{array}{c}\text { Pod No./ } \\
\text { plant }\end{array}$} & \multicolumn{2}{c|}{$\begin{array}{c}\text { Pod Weight } \\
\text { (g/plant) }\end{array}$} \\
\cline { 2 - 12 } $\mathbf{1}^{\text {st }}$ & $\mathbf{2}^{\text {nd }}$ & $\mathbf{1}^{\text {st }}$ & $\mathbf{2}^{\text {nd }}$ & $\mathbf{1}^{\text {st }}$ & $\mathbf{2}^{\text {nd }}$ & $\mathbf{1}^{\text {st }}$ & $\mathbf{2}^{\text {nd }}$ & $\mathbf{1}^{\text {st }}$ & $\mathbf{2}^{\text {nd }}$ \\
\hline Control & 0.073 & 0.083 & 0.517 & 0.600 & 0.464 & 0.516 & 8.69 & 9.86 & 3.20 & 3.82 \\
\hline $\mathrm{Nu}$ & 0.120 & 0.130 & 0.767 & 0.877 & 0.436 & 0.469 & 10.45 & 12.82 & 4.07 & 4.17 \\
\hline $\mathrm{HA}$ & 0.123 & 0.130 & 0.763 & 0.877 & 0.406 & 0.463 & 16.03 & 14.96 & 5.80 & 5.06 \\
\hline $\mathrm{SA}$ & 0.083 & 0.093 & 0.627 & 0.733 & 0.373 & 0.397 & 12.33 & 13.81 & 5.50 & 5.06 \\
\hline $\mathrm{Nu}+\mathrm{HA}$ & 0.113 & 0.127 & 0.790 & 0.890 & 0.428 & 0.443 & 20.27 & 18.44 & 6.80 & 5.55 \\
\hline $\mathrm{Nu}+\mathrm{SA}$ & 0.130 & 0.137 & 0.653 & 0.763 & 0.403 & 0.426 & 16.30 & 14.09 & 5.19 & 4.82 \\
\hline $\mathrm{HA}+\mathrm{SA}$ & 0.110 & 0.130 & 0.740 & 0.850 & 0.367 & 0.401 & 17.40 & 15.92 & 6.27 & 5.25 \\
\hline $\mathrm{Nu}+\mathrm{HA}+\mathrm{SA}$ & 0.137 & 0.150 & 0.803 & 0.893 & 0.379 & 0.417 & 20.03 & 18.81 & 6.93 & 5.78 \\
\hline L.S.D. (5\%) & 0.021 & 0.019 & 0.017 & 0.034 & 0.029 & $\mathrm{NS}$ & 0.663 & 0.044 & 0.253 & 0.028 \\
\hline
\end{tabular}

The highest value of chlorophyll "a" (0.150) was observed by spraying of $\mathrm{Nu}+\mathrm{HA}+\mathrm{SA}(80.72 \%)$ followed by $\mathrm{Nu}+\mathrm{SA}(65.06 \%)$, both treatments resulted in significant increases compared with the control. Chlorophyll "b" content increased when plants treated with $\mathrm{Nu}+\mathrm{HA}+\mathrm{SA}(0.803$ and 0.893 during both seasons, respectively) followed by $\mathrm{Nu}+\mathrm{HA}(0.790$ and 0.890 during first and second seasons, respectively). Regarding carotenoids content in fenugreek leaves, control (water spray) produced maximum content of carotenoids pigment (0.516) followed by Nutrifol (0.469) in comparison with other treatments. HA $+\mathrm{SA}$ and Salicylic acid individually produced the lowest value of carotenoids content in the first and second seasons.

The same trend of result was observed by different previous authors such as Khattab and Omer (1990) who reported a promotive effect of zinc application on plant growth and yield of fennel. The positive effect of zinc may be due to the fact that zinc favours the enzyme system, auxin and protein synthesis and seed production directly or indirectly (Sharma et al., 1999). Increment in fennel seed yield of $19.05 \%$ was recorded by Sharangi et al., (2002) due to the application of boron at lower concentrations. The positive effect may be due to increasing value of pod number per plant, seed number per pod and the test weight.

Considering yield components, the maximum number of pods per plant was found with $\mathrm{Nu}+\mathrm{HA}$ at $133.26 \%$ (20.27) closely followed by $\mathrm{Nu}+\mathrm{HA}+\mathrm{SA}$ at $130.49 \%$ (20.03) during the first season, in the second one the same treatments has also been observed as the superior in comparison with other treatments but each of them exchanged its location with the another. The heaviest pod/plant (6.93 and $5.78 \mathrm{~g}$ in the first and second seasons, respectively) was also observed in $\mathrm{Nu}+\mathrm{HA}+\mathrm{SA}$ followed by $\mathrm{Nu}+\mathrm{HA}$ (6.80 and $5.55 \mathrm{~g}$ in the both seasons). The lightest pod/plant was noticed in the control producing 3.20 and $3.82 \mathrm{~g}$ in the first and second seasons, respectively).

Seed weight/plant, seed yield/feddan and thousand seed 
weight are presented in Table 3 . The seed weight per plant was maximum $(2.96 \mathrm{~g})$ in the plants treated with $\mathrm{Nu}+\mathrm{HA}+\mathrm{SA}$ followed by $\mathrm{HA}+\mathrm{SA}$ $(2.64 \mathrm{~g})$. Similar observation was found in seed yield/feddan as recorded 1182.7 and $1057.3 \mathrm{~kg}$ for both treatments, respectively. Also, parameter of thousand seed weight showed the same trend where $\mathrm{Nu}+\mathrm{HA}+\mathrm{SA}$ recorded the heaviest $(17.80 \mathrm{~g})$ followed by HA+SA (16.40 g), however the control treatment produced the lightest thousand seed weight (13.10 g).

Tuncturk and Tuncturk (2017) declared that humic acid applications have positive effects on fenugreek plant growth, yield and quality parameters. In addition to the impact of humic substances on the soils (physical, chemical and biological properties), they have a direct effect on plant growth. It was recorded that the best seed yield $(916.0 \mathrm{~kg} / \mathrm{ha})$ was obtained from $900 \mathrm{~kg} / \mathrm{ha}$ humic acid dose application.

The economic parameters of fenugreek for this experiment are fixed oil percentage, fixed oil yield and steroidal saponin content in defatted seeds. So, the fixed oil production increased of $72.77 \%$ over control with spraying of $\mathrm{Nu}+\mathrm{HA}+\mathrm{SA}$. The maximum fixed oil percentage $(6.18$ and $6.41 \%$ in the first and second seasons, respectively) was obtained with $\mathrm{Nu}+\mathrm{HA}+\mathrm{SA}$ followed by $\mathrm{HA}+\mathrm{SA}$ (5.33 and $5.53 \%$ in both seasons). The same parameter trend has also been observed in the fixed oil yield/feddan. Spraying of $\mathrm{Nu}+\mathrm{HA}+\mathrm{SA}$ and $\mathrm{HA}+\mathrm{SA}$ produced maximum yield at rate 73.04 and $56.32 \mathrm{~kg} /$ fedan in the first season and 71.71 and $50.17 \mathrm{~kg} /$ fedan in the second one, respectively. The control plot (water spray) produced the lowest values in both seasons (Table 3 ). To interpret these results, the effect of SA on plant functions should be understood. Salicylic acid is an effective factor in regulating plant growth processes as previously shown by Singh (1993) who found that SA stimulated root formation in young shoots of ornamental plants. Spraying SA at the flowering stages of cotton increased boll numbers as resulted by Hampton and Oosterhuis (1990). This positive effect could be explained upon the effect of SA on increasing $\mathrm{CO} 2$ assimilation and accordingly photosynthetic rate in addition to the increase in mineral uptake (Karlidage et al. 2009). An additional explanation for the promotive influence of SA on growth and yield might be its effect on the hormonal status of the plant which involve the auxin, cytokinin and ABA balances (Shakirova, 2007). 
Website: www.aun.edu.eg/faculty_agriculture/journals_issues_form.php E-mail:ajas@aun.edu.eg

Table 3. Effect of foliar application of growth promoting substances on seed productivity and fixed oil content of fenugreek plants during 2016/2017 and 2017/2018 seasons.

\begin{tabular}{|c|c|c|c|c|c|c|c|c|c|c|}
\hline \multirow[t]{2}{*}{ Treatments } & \multicolumn{2}{|c|}{$\begin{array}{c}\text { Seed weight } \\
\text { (g/plant) }\end{array}$} & \multicolumn{2}{|c|}{$\begin{array}{l}\text { Seed yield } \\
\text { (kg/feddan) }\end{array}$} & \multicolumn{2}{|c|}{$\begin{array}{l}\text { Weight of } \\
1000 \text { seed } \\
\text { (g) }\end{array}$} & \multicolumn{2}{|c|}{$\begin{array}{c}\text { Fixed oil } \\
\%\end{array}$} & \multicolumn{2}{|c|}{$\begin{array}{c}\text { Fixed oil } \\
\text { yield } \\
\text { (l/feddan) }\end{array}$} \\
\hline & $1^{\text {st }}$ & $2^{\text {nd }}$ & $1^{\text {st }}$ & $2^{\text {nd }}$ & $1^{\text {st }}$ & $2^{\text {nd }}$ & $1^{\text {st }}$ & $2^{\text {nd }}$ & $1^{\text {st }}$ & $2^{\text {nd }}$ \\
\hline Con & 1.52 & 1.37 & 606.7 & 546.7 & 13.10 & 13.44 & 3.53 & 3.71 & 21.39 & 20.31 \\
\hline $\mathrm{Nu}$ & 2.08 & 1.75 & 830.7 & 698.7 & 14.30 & 14.66 & 4.82 & 4.97 & 40.06 & 34.70 \\
\hline $\mathrm{HA}$ & 2.55 & 2.20 & 1021.3 & 880.0 & 15.12 & 15.16 & 4.37 & 4.22 & 44.63 & 37.16 \\
\hline $\mathrm{SA}$ & 1.76 & 1.87 & 704.0 & 748.0 & 14.40 & 14.50 & 3.74 & 3.94 & 26.33 & 29.47 \\
\hline $\mathrm{Nu}+\mathrm{HA}$ & 2.15 & 2.09 & 860.0 & 836.0 & 15.17 & 15.34 & 5.96 & 6.17 & 51.23 & 51.55 \\
\hline $\mathrm{Nu}+\mathrm{S}$ & 2.03 & 2.09 & 810.7 & 834.7 & 15.03 & 14.93 & 4.41 & 4.55 & 35.75 & 37.95 \\
\hline $\mathrm{HA}+\mathrm{SA}$ & 2.64 & 2.27 & 1057.3 & 906.7 & 16.40 & 15.42 & 5.33 & 5.53 & 56.32 & 50.17 \\
\hline $\mathrm{Nu}+\mathrm{HA}+$ & 2.96 & 2.80 & 1182.7 & 1118.7 & 17.80 & 16.91 & 6.18 & 6.41 & 73.04 & 71.71 \\
\hline L.S.D. (5\%) & 0.096 & 0.033 & 38.659 & 13.238 & 0.296 & 0.070 & 0.111 & 0.372 & 2.038 & 3.407 \\
\hline
\end{tabular}

As shown in Figure 1, significant effect of $\mathrm{Nu}+\mathrm{HA}+\mathrm{SA}$ treatments was found on the steroidal saponin content for both seasons. In terms of growth promoting applications, the highest value was obtained as 4.82 and $4.12 \mathrm{mg} / \mathrm{g}$ defatted extract from plants treated with $\mathrm{Nu}+\mathrm{HA}+\mathrm{SA}$ during the first and second seasons, respectively. But, the lowest values were obtained as 2.26 and $1.91 \mathrm{mg} / \mathrm{g}$ defatted extract from plants sprayed with water only (control) during the first and second seasons, respectively.

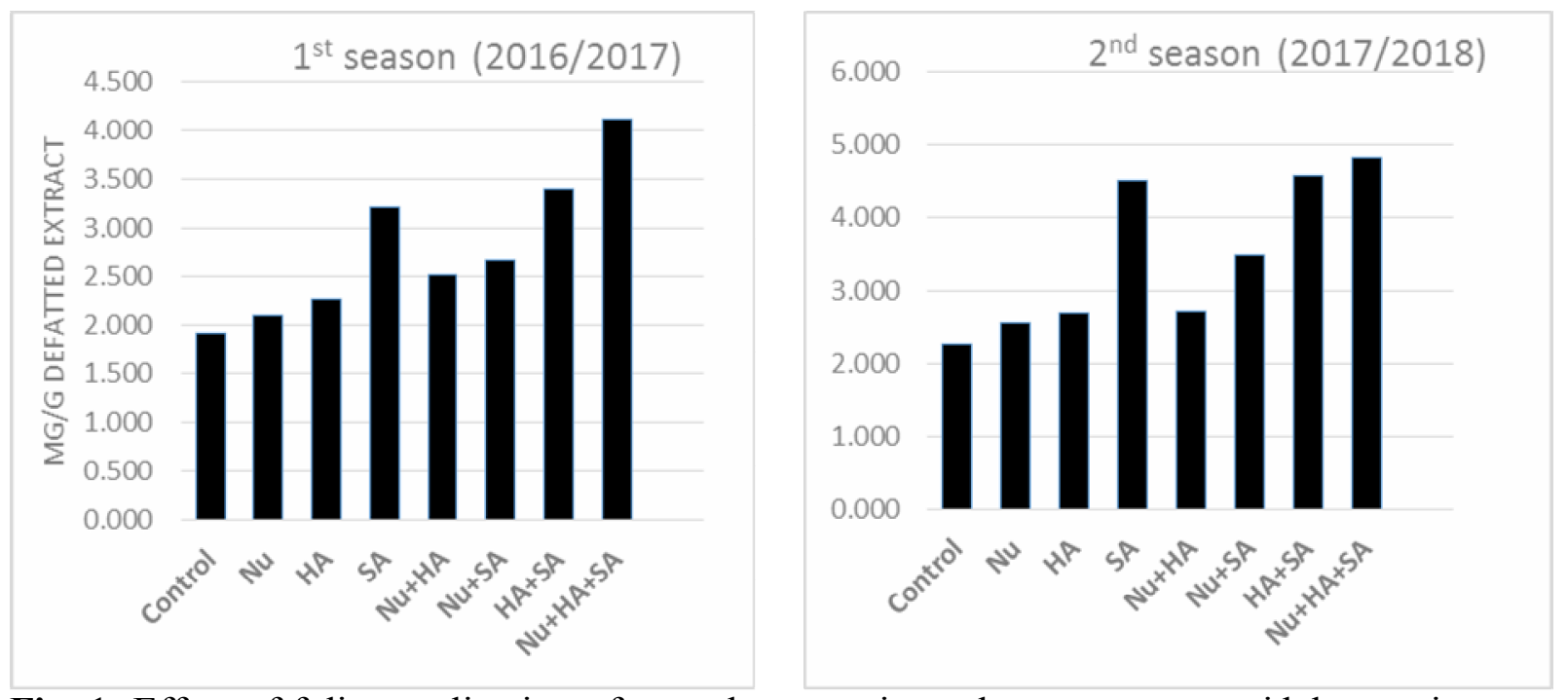

Fig. 1. Effect of foliar application of growth promoting substances on steroidal saponins content of fenugreek plants during 2016/2017 and 2017/2018 seasons. 


\section{Conclusions:}

From results obtained, it could be concluded that foliar application of micronutrients, humic acid, salicylic acid and their combinations, are useful for improving the productivity and seed content of steroidal saponins of fenugreek plants. Accordingly, it is recommended to use humic acid alone or combined with any of salicylic acid and the foliar fertilizer or togeather to achieve the best yield characteristics including seed and oil yield per fedan and total content of steroidal saponins.

\section{References:}

Abdelaal, Kh. A. A. (2015). Effect of salicylic acid and abscisic acid on morpho-physiological and anatomical characters of faba bean plants (Vicia faba L.) under drought stress. J. Plant Production, Mansoura Univ., 6 (11): 1771 1788.

Aishwath, O.P.; H.S. Khurana and M. M. Anwer (2011). A review on the effect of integrated nutrient management on yield and quality of major seed spice crops in India. Better Crops-South Asia, 5 (1): 1921.

Arif, M.; M.A. Khan; H. Akbar and S. Ali (2006). Respects of wheat as a dual purpose crop and its impact on weeds. Pak. J. Weed Sci. Res., 12 (1-2): 13-17.

Baccou, J.C.; F. Lambert and Y. Sauvaire (1977). Spectrophotometric Method for the Determination of Total Steroidal Sapogenin. Analyst, Jwze, 102: 458-465.

Black, C.A.; D.D. Evans; J.I. White; L.E. Ensminger and F.E. Clark (1982). Methods of Soil Analysis. Ameri. Soc. Agron., Soil Sci. Soc. Amer., Madison, Wisconsin, USA

Chen, Y. and T. Aviad (1990). Effect of humic substances on plant growth. in: humic substances in soil and crop sciences: Selected Readings, Ed., P. Maccarthy, Am. Soc. of Agron. and Soil Sci. Soc. Am., Madison, Wisconsin, pp: 161-186.

Chhibba, I.M.; V.K. Nayyar and J.S. Kanwar (2007). Influence of Mode and Source of Applied Iron on Fenugreek (Trigonella corniculata L.) in a TypicUstochrept in Punjab, India. Intern. J. Agric. \& Bio., 9 (2): 254-256.

Dahanukar, S.A.; R.A. Kulkarni and N.N. Rege (2000). Pharmacology of medicinal plants and natural products. Indian J. Pharmacol., 32: S81-S118.

David, P.P.; P.V. Nelson and D.C. Sanders (1994). A humic acid improves growth of tomato seedling in solution culture. J. Plant Nutr., 17 (1): 173-184.

Davies, P.J. (2004). Plant hormones: Their nature, occurrence and functions. In: Davies PJ (ed) Plant Hormones: Biosynthesis, Signal Transduction, Action, Kluwer Academic Publishers, London, p: $1-15$.

Edison, S. (1995). Spices-Research support to productivity. In N. Ravi (ed.) The Hindu Survey of Indian Agriculture, Kasturi and Sons Ltd., National Press, Madras: p.101-105.

Fagbenro, J.A. and A.A. Agboda (1993). Effect of different levels of humic acid on the growth and nutrient uptake of teak seedings. J. Plant Nutr., 16 (8): 1465-1483.

Fazli, F.R.Y. and R. Hardman (1968). The spice fenugreek (Trigonella foenum-graecum L.). Its commercial varieties of seed as a source of diosgenin. Trop. Sci., 10:66-78.

Hampton, R.E. and D.M. Oosterhuis (1990). Application of phenolic acids to manipulate boll distribution in cotton. Arkansas Farm. Res., 39: 11-18. 
Hayat, S.; B. Ali and A. Ahmad (2007). Salicylic acid: biosynthesis, metabolism and physiological role in plants. In: Hayat S, Ahmad A (eds) Salicylic Acid: A Plant Hormone, Springer, Dordrecht, The Netherlands, p: 1-14.

Hegazi, A.M. and A.M. El-Shrayi (2007). Impact of salicylic acid and paclobutrazol exogenous application on the growth, yield and nodule formation of common bean. Aust J. Basic Appl. Sci., 1: 834840.

Hosam El-Din, A.T.S. (2007). Productivity of some wheat varieties by using bio and organicfertilization in the New Valley. M. Sc. Thesis, Fac. Agric. Ain Shams Univ., Egypt.

Hussein, M.M.; L.K. Balbaa and M.S. Gaballah (2007). Salicylic acid and salinity effects on growth of maize plants. Res. J. Agric. Biol. Sci., 3: 321-328.

Jackson, M.L. (1973). Soil Chemical Analysis. Prentic-Hall. Inc. Englewood, Cliffs, USA.

Karlidag, H.; E. Yildirim and M. Turan (2009). Salicylic acid ameliorates the adverse effect of salt stress on strawberry. Sci. Agric., 66: 180187. Doi:10.1590/S0103-9016200 9000200006

Khattab, M.E. and E.A. Omer (1999). Influence of excessive fertilization with micronutrients on the growth yield, essential oil and micro element of some Apiaceae plant. Egyptian J. Hort. P1., 26: 249-266.

Krishnan, P.; I. Ravi and S.K. Nayak (1996). Methods for determining leaf chlorophyll content of rice: A reappraisal. Indian J. Exp. Biol., 34: 1030-1033.

Kulikova, N.A.; E.V. Stepanova and O.V. Koroleva (2005). Mitigating Activity of Humic Substances Direct Influence on Biota. In: Use of
Humic Substances to Remediate Polluted Environments: from Theory to Practice (Eds I. V. Perminova, K. Hatfield, N. Hertkorn). Springer, Chapter 14: p. 285.

Lal, G.B.; R.S. Singh; R.M. Singh and S.P. Maheria (2015). Performance of fenugreek (Trigonella foenum graecum L.) as influenced by sulphur and zinc. Inter. J. Seed Spices, 5 (1): 29-33.

Lust, J.B. (1986). The herb book. Bantam Books Inc. New York: p. 1-55.

Martínez, C.; E. Pons; G. Prats and J. León (2004). Salicylic acid regulates flowering time and links defence responses and reproductive development. Plant J., 37: 209217. Doi:10.1046/j.1365-313X. 2003.01954.X

McAnuff, M.A.; F.O. Omoruyi; E.Y.S.A. Morrison and H.N. Asemota (2002). Plasma and liver lipid distributions in streptozotocininduced rats fed sapogenin extract of the Jamaican bitter yam (Dioscorea polygonoides). Nutr. Res., 22: 1427-1434.

Nadim, M.A.; I.U. Awan; M. S. Baloch; E.A. Khan, A. Naved and M.A. Khan (2012). Response of (Triticum aestivum, L.) to different micronutrients and their application methods. J. Animal\& Plant Sci., 22 (1):113-118.

Noreen, S.; M. Ashraf; M. Hussain and A. Jamil (2009). Exogenous application of salicylic acid enhances antioxidative capacity in salt stressed sunflower (Helianthus annus L.) plants. Pakistan J. Bot., 41: 473-479.

Padem, H. and A. Ocal (1999). Effect of Humic Acid Applications on Yield and Some Characteristics of Processing Tomato. Acta Horticulturae, 487: 159.

Pariari, A.; S. Khan and M. N. Imam (2009). Influence of boron and 
zinc on increasing productivity of Fenugreek seed (trigonella foenum graecum L.). J. Crop and Weed, 5 (2): 57-58.

Petropoulos, G.A. (2002). Fenugreek The genus Trigonella, 1st ed. Taylor and Francis, London and New York: p. 1-127.

Raghuram, T.C.; R.D. Sharma and B. Sivakumar (1994). Effect of fenugreek seeds on intravenous glucose disposition in non-insulin dependent diabetic patients. Phytother. Res., 8: 83-86.

Shakirova, F.M. (2007). Role of hormonal system in the manisfestation of growth promoting and anti-stress action of salicylic acid. In: Hayat S. and Ahmad A (eds) Salicylic Acid, A Plant Hormone, Springer, Dordrecht, Netherlands, p:69-90.

Sharangi A.B.; A. Pariari; R. Chattarjee and D.K. Das (2002). Response of boron and zinc on growth and seed yield of fennel. J. Interacad., 6: 472-475.

Sharma, S.K.; H. Swing and U.K. Kohli (1999). Influence of B and $\mathrm{Zn}$ on seed yield and quality of Radish. Seed Res., 27: 154-158.

Singh, B. and K. Usha (2003). Salicylic acid-induced physiological and biochemical changes in wheat seedlings under water stress. Plant Growth Regul., 39: 137-141. Doi:10.1023/A:1022556103536

Singh, S.P. (1993). Effect of non-auxinic chemicals on root formation in some ornamental plant cuttings. Adv. Hortic. For., 3: 207-210.

Snedecor, G.W. and W.G. Cochran (1989). Statistical Methods. $8^{\text {th }}$ ed,
Iowa State University Press,Ames. Iowa, USA.

Steel, R.G. and T.H. Torrie (1982). Principles and Procedures of Statistics. McGraw-Hill International Book Company, $3^{\text {rd }}$ ed., London.

Stevenson, F.J. (1994). Humus Chemistry: Genesis, Composition, Reactions. 2nd ed. John Wiley and Sons Inc., New York.

Tipping, E. (2002). Cation Binding by Humic Substances. Cambridge University Press, Cambridge, U.K.

Tuncturk, R. and M. Tuncturk (2017). Effects of humic acid and Rhizobium inoculation on the yield and quality of fenugreek (Trigonella foenum-graecum L.). J. of Environ. Protection and Ecology, 18 (3): 922-929.

Tuncturk, R.; H. Kulaz and M. Tuncturk (2016). Effect of Humic Acid Applications on Some Nutrient Contents of Soybean (Glycine max L.) Cultivars. Oxid Commun. 39 (1): 503.

Uematsu, Y.; K. Hirata; K. Saito and I. Kudo (2000). Spectrophotometric determination of saponin in Yucca extract used as food additive. J. AOAC Int., 83:1451-1454.

Wang, Y. and T.A. McAllister (2010). A modified spectrophotometric assay to estimate deglycosylation of steroidal saponin to sapogenin by mixed ruminal microbes. J. Sci. Food Agric., 90:1811-1818.

Yilmaz, C. (2007). Humic and Fulvic Acid. Hasad Crop Produc. January, 260: 74 . 
تحسين نمو نبات الحلبة ومحتوى الصابونينيات الستيرونيديه بالمعاملة الورقية ببعض المواد المنشطة للنمو

\section{عصام يوسف عبد الحفيظ}

قسم نباتات الزينة ونتسيق الحدائق، كلية الزر اعة ، جامعة أسيوط

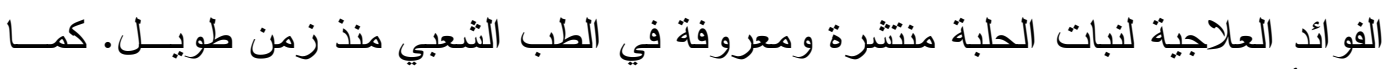

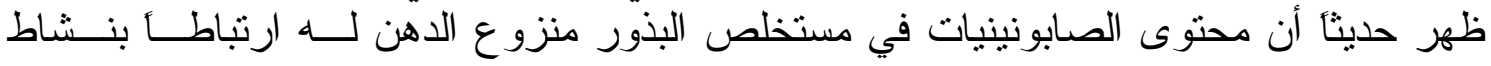

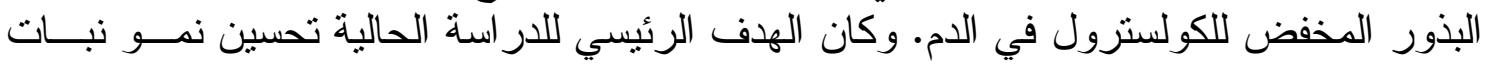

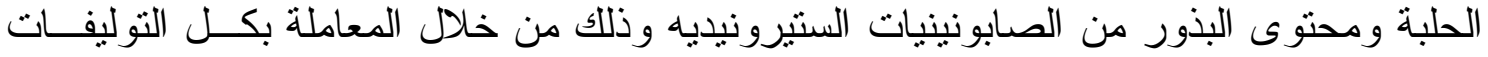

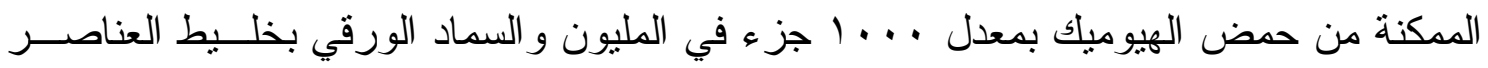

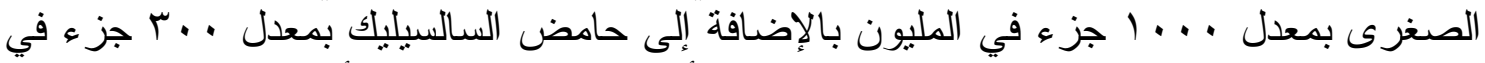

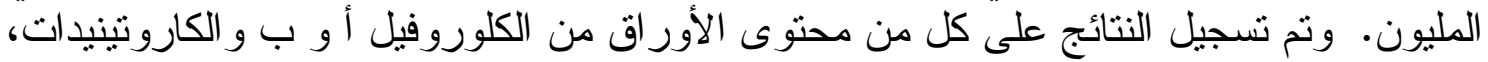

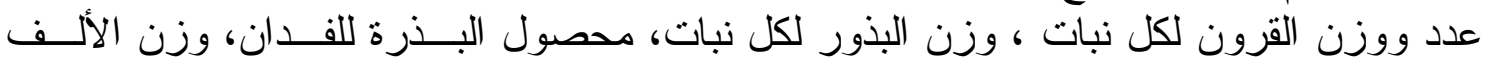

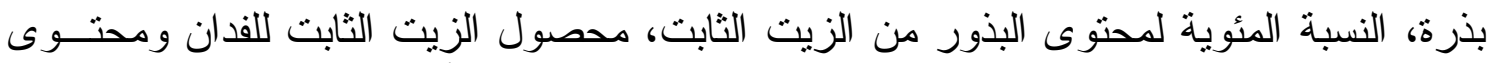

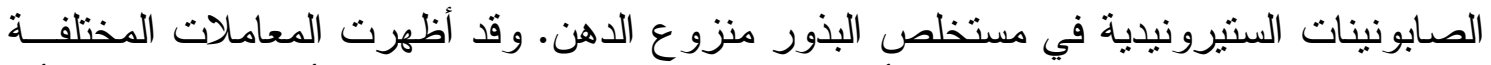

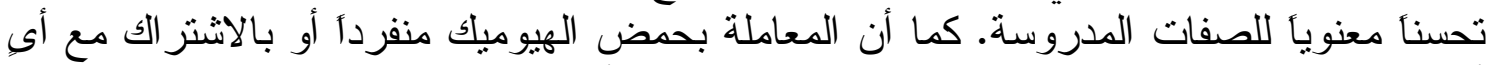

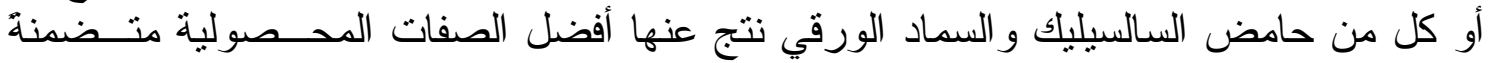
محصول البذور و الزيت للفدان و المحتوى الكلى للصنابونينات الستيرونيدية. 